ARTICLE

Check for updates

https://doi.org/10.1057/s41599-020-0468-6

\title{
Models of good teaching practices for mobile learning in higher education
}

\author{
José-María Romero-Rodríguez (iD) ${ }^{1 凶}$, Inmaculada Aznar-Díaz (i) ${ }^{1}$, Francisco-Javier Hinojo-Lucena (i) ${ }^{1}$ \& \\ María-Pilar Cáceres-Reche (iD ${ }^{1}$
}

\begin{abstract}
Mobile learning is an emerging teaching methodology in the university system. Every year, the International Horizon Reports highlight the trend of implementing mobile devices in the classroom. Therefore, the Spanish university system presents the current challenge of adapting these resources to improve student learning, in line with the knowledge society in which we are immersed. This requires examples of good teaching practice. The purposes of this paper were to evaluate the mobile learning (m-learning) practices implemented by university teachers and to compile experiences on good teaching practices of $\mathrm{m}$ learning developed in the classroom. A mixed method was used in which the responses of 1125 professors from 59 different universities located throughout Spain were analyzed. The APMU scale developed by the authors was applied for the detection of good teaching practices of m-learning and the structured interview for the collection of concrete experiences of good teaching practices. The results showed that the largest proportion of good teaching practices were concentrated at the University of La Laguna, University of Almeria, University of La Rioja, Camilo José Cela University and University of Seville. Furthermore, three experiences carried out by teachers who were agents of good practice were collected. Based on this, three models of good teaching practices were generated and exemplified through the concept mapping technique. Finally, the main findings and implications of the study are discussed.
\end{abstract}

\footnotetext{
${ }^{1}$ University of Granada, Granada, Spain. ${ }_{\text {email: romejo@ugr.es }}$
} 


\section{Introduction}

$\mathrm{n}$ recent years, the use of mobile devices in education (mainly smartphones and tablets) is becoming increasingly important. The Horizon Reports have been highlighting this trend for some years now, specifying that mobile learning (m-learning) will be implemented in one year or less at the higher education stage (Alexander et al., 2019). This indicates the importance attached to the application of this resource in the classroom.

Thus, m-learning is defined as the use of mobile devices to support the teaching-learning process (Díez et al., 2017). The potential of the use of mobile devices in education lies in their main characteristics, which are the mobility they allow, ubiquity (being able to be used at any time and place), lightness, low cost, and connectivity (Arain et al., 2019). In this way, m-learning contributes to the transformation of teaching practice (Boude, 2019), since it is based on the current of student-based teaching, where the teacher acts only as a guide to learning.

In Spain, experiences have begun to be developed in the levels of pre-school and primary education that highlight the increase in motivation (Gil, 2019). In turn, some studies corroborate the effectiveness of m-learning in improving student learning (Bai, 2019; Fox, 2019). Furthermore, students perceive it as a useful tool for their learning, since it favors self-regulation (Hossain et al., 2019; Lim et al., 2019). Therefore, the possibility that mlearning allows to be connected at any time and place, has a direct impact on the self-management of learning by the student, where they are the ones who establish the schedule and time that best suits their individual needs to perform the tasks.

On the other hand, the development of digital competence is another of the implications of m-learning (Fuentes et al., 2019; Rodríguez et al., 2017; Pinto et al., 2019). This is essential in Spain, since the National Institute of Educational Technologies and Teacher Training of Spain (INTEF, 2017) has already stressed the importance of training students in digital skills in order to be fully equipped in the digital society in which we find ourselves.

In relation to teachers, Salcines-Talledo et al. (2017) highlight that there are three teaching profiles in the use of the smartphone: promoters, professionally initiated, and non-professional users. This refers to the degree of commitment and acquisition of digital skills for the educational implementation of mobile devices, where the drivers are those with the highest degree of application experience. These promoters would be the so-called agents of good teaching practices (GTP), which stand out for carrying out m-learning experiences with satisfactory results for the students (Alonso-García et al., 2019). Therefore, it is important to locate these teachers in order to compile the teaching experience carried out and to make it transferable to other contexts because of its excellence.

On the other hand, we should not forget certain studies that warn of the risks of mobile devices for health (Qi, 2019; Stilgoe, 2016), where their abusive use can end up in addictive behaviors (Arpaci and Unver, 2020; Chen, 2020; Cevik et al., 2020). Therefore, education in the good use of technology linked to the development of GTP is essential. This is key to diminishing the negative aspects of mobile devices while educating in their good use.

In relation to previous studies of m-learning in higher education, different research trends are collected. On the one hand, we find studies focused on the adoption of m-learning (Fagan, 2019; Gómez-Ramírez et al., 2019; Hoi, 2020; Israel and Velu, 2019; Kaliisa et al., 2019; Kumar and Bervell, 2019; López and Silva, 2016; Saroia and Gao, 2019). Others focused on establishing an m-learning framework (Benali and Ally, 2020; Irugalbandara and Fernando, 2019; Jinot, 2019; Xue, 2020). Of a more practical nature where experiences of application are gathered (Jahnke and Liebscher, 2020; Kumar et al., 2019; Vacas et al., 2019; Vasilevski and Birt, 2020). And those studies based on the development of GTP of m-learning (Caldeiro-Pedreira et al., 2018; GonzálezFernández and Salcices-Talledo, 2017; Navarro et al., 2018).

Hence, the number of investigations focused on the perception and adoption of $\mathrm{m}$-learning is much greater than the studies of a practical nature, where applications and GTP of m-learning are collected. Based on these facts, it was proposed to revert this tendency through a pioneering study that had as objectives (i) to evaluate the m-learning practices implemented by Spanish university teachers and (ii) to compile experiences on GTP of mlearning developed in the classroom. In consideration, they were raised as research questions:

RQ1: What was the frequency of development of good teaching practices of m-learning?

RQ2: In which universities were the good teaching practices of m-learning located?

RQ3: Are there significant differences according to gender, age, or institution in the development of good teaching practices of m-learning?

RQ4: What were the m-learning experiences that you highlighted as examples of good teaching practice?

\section{Method}

The methodology used in the research was a mixed method (Johnson and Onwuegbuzie, 2004). This was motivated by the fact that it is one of the most widely used methodologies in educational research (Pereira, 2011). In addition, it was the most appropriate to respond to the objectives of the study which are both quantitative and qualitative.

Participants and procedure. A cross-sectional study approach was adopted, where research was carried out on the basis of a convenience sampling design. The study sample was focused on the population of university professors in the Faculties of Education of the Spanish universities with face-to-face teaching. The data of the participants was collected from the email distribution of an online survey, made with the help of Google Forms. In total, professors from 59 Spanish universities participated, of which 40 were public and 19 private $(n=1125)$.

Before answering the scale, participants gave their informed consent. All respondents were given information about the purpose of the study and the anonymous processing of their data. Thus, the participants answered a series of questions related to their sociodemographic data (gender, age, and university) and a scale to evaluate GTP of m-learning in the university environment. Subsequently, based on their responses on the scale, three potential teachers were selected who stood out for their scores as agents of GTP. These three people were invited to conduct an interview to compile the m-learning experience they applied in their classroom. The data collection period was from May 2019 to January 2020.

The sample was defined by 434 men and 691 women, aged between 20 and 77 years $(M=44.66 ; \mathrm{SD}=10.36)$. Table 1 shows the sociodemographic data of the participants.

\section{Measures}

Analysis of M-learning practices at the University (APMU). A scale developed by the authors was used to carry out the evaluation of GTP in m-learning by university teachers. The instrument consists of 16 items to identify whether teachers apply GTP with mobile devices. Specifically, the items are divided into five dimensions: mobile devices, digital competence, knowledge construction, cooperative work, and good use of technology. The responses on the scale are grouped based on frequency, where 


\section{Table 1 Sociodemographic data.}

\begin{tabular}{|c|c|c|}
\hline & $n$ & $\%$ \\
\hline \multicolumn{3}{|l|}{ Gender } \\
\hline Male & 434 & 38.6 \\
\hline Female & 691 & 61.4 \\
\hline \multicolumn{3}{|l|}{ Age } \\
\hline $20-29$ & 79 & 7 \\
\hline $30-39$ & 293 & 26 \\
\hline $40-49$ & 374 & 33.2 \\
\hline $50-59$ & 281 & 25 \\
\hline 60 or more & 98 & 8.7 \\
\hline \multicolumn{3}{|l|}{ University } \\
\hline University of Almeria (UAL) & 12 & 1.1 \\
\hline University of Cadiz (UCA) & 20 & 1.8 \\
\hline University of Cordoba (UCO) & 16 & 1.4 \\
\hline University of Granada (UGR) & 76 & 6.8 \\
\hline University of Huelva (UHU) & 16 & 1.4 \\
\hline University of Jaen (UJAEN) & 8 & 0.7 \\
\hline University of Malaga (UMA) & 22 & 2 \\
\hline Pablo de Olavide University (UPO) & 5 & 0.4 \\
\hline University of Seville (US) & 41 & 3.6 \\
\hline Loyola of Andalusia University (ULOYOLA) & 4 & 0.4 \\
\hline University of Zaragoza (UNIZAR) & 39 & 3.5 \\
\hline San Jorge University (USJ) & 6 & 0.5 \\
\hline University of Oviedo (UNIOVI) & 20 & 1.8 \\
\hline University of La Laguna (ULL) & 17 & 1.5 \\
\hline University of Las Palmas de Gran Canaria (ULPGC) & 19 & 1.7 \\
\hline University of Cantabria (UNICAN) & 11 & 1 \\
\hline University of Burgos (UBU) & 16 & 1.4 \\
\hline University of León (UNILEON) & 9 & 0.8 \\
\hline University of Salamanca (USAL) & 12 & 1.1 \\
\hline University of Valladolid (UVA) & 34 & 3 \\
\hline Catholic University of Avila (UCAVILA) & 2 & 0.2 \\
\hline Pontifical University of Salamanca (UPSA) & 12 & 1.1 \\
\hline University of Castilla-La Mancha (UCLM) & 23 & 2 \\
\hline Autonomous University of Barcelona (UAB) & 25 & 2.2 \\
\hline University of Barcelona (UB) & 59 & 5.2 \\
\hline University of Girona (UDG) & 15 & 1.3 \\
\hline University of Lleida (UDL) & 8 & 0.7 \\
\hline Rovira i Virgili University (URV) & 15 & 1.3 \\
\hline Abat Oliba CEU University (UAO) & 3 & 0.3 \\
\hline International University of Catalonia (UIC) & 10 & 0.9 \\
\hline Ramón Llull University (URL) & 13 & 1.2 \\
\hline University of Vic (UVIC) & 8 & 0.7 \\
\hline University of Alcala (UAH) & 16 & 1.4 \\
\hline Autonomous University of Madrid (UAM) & 29 & 2.6 \\
\hline Complutense University of Madrid (UCM) & 53 & 4.7 \\
\hline Rey Juan Carlos University (URJC) & 8 & 0.7 \\
\hline Alfonso X El Sabio University (UAX) & 1 & 0.1 \\
\hline Camilo José Cela University (UCJC) & 11 & 1 \\
\hline Francisco de Vitoria University (UFV) & 10 & 0.9 \\
\hline Nebrija University (UNEBRIJA) & 6 & 0.5 \\
\hline Pontifical University of Comillas (UCOMILLAS) & 10 & 0.9 \\
\hline University of Alicante (UA) & 27 & 2.4 \\
\hline Jaume I University (UJI) & 18 & 1.6 \\
\hline University of Valencia (UV) & 39 & 3.5 \\
\hline Cardenal Herrera University (CEU-UCH) & 14 & 1.2 \\
\hline Catholic University of Valencia San Vicente Martir (UCV) & 33 & 2.9 \\
\hline University of Extremadura (UNEX) & 31 & 2.8 \\
\hline University of A Coruña (UDC) & 10 & 0.9 \\
\hline University of Santiago de Compostela (USC) & 26 & 2.3 \\
\hline University of Vigo (UVIGO) & 15 & 1.3 \\
\hline University of Islas Baleares (UIB) & 21 & 1.9 \\
\hline University of La Rioja (UNIRIOJA) & 6 & 0.5 \\
\hline Public University of Navarra (UNAVARRA) & 14 & 1.2 \\
\hline University of Navarra (UNAV) & 12 & 1.1 \\
\hline University of País Vasco (UPV) & 52 & 4.6 \\
\hline University of Deusto (DEUSTO) & 20 & 1.8 \\
\hline Mondragon University (MONDRAGON) & 5 & 0.4 \\
\hline University of Murcia (UM) & 29 & 2.6 \\
\hline Catholic University of San Antonio (UCAM) & 13 & 1.2 \\
\hline
\end{tabular}

they are categorized on a four-level Likert scale where 1 is never and 4 is always. Thus, the scores on the scale range from a minimum of 16 to a maximum of 64 points, with the cut-off at $\geq 48$ points to estimate that teachers are applying GTP of $\mathrm{m}$ learning. An adequate internal consistency was obtained for this study (Cronbach's $\alpha=0.83$ ).
Structured interview. The structured interview had the objective of compiling the experiences cataloged as GTP, this technique being appropriate for collecting data of a more in-depth nature to allow for the interpretation of the actions carried out by the participants under study (Valles, 2009). The questions were formulated on the basis of three sources of information:

- The definition of GTP of m-learning: "Learning that is established through the mediation of mobile digital devices for the development of digital competence, which implies the construction of knowledge, self-regulation of learning, and cooperative work" (Aznar-Díaz et al., 2018, p. 55).

- The common aspects of GTP with ICT: (i) Focus on the student, (ii) encourage collaborative work, and (iii) promote autonomy (Alonso-García et al., 2019).

- Previous studies on GTP (Aznar-Díaz et al., 2019; Fernández et al., 2012; González et al., 2010; Martínez, 2011; Zabalza, 2012).

Based on this, the questions that made up the structured interview were developed and applied to three university teachers who stood out for their answers on the APMU scale. The questions were grouped into the following dimensions: 1 . Dynamic; 2. Context; 3. Purpose; 4. Materials and resources; 5. Problem solving; 6. Time evolution; 7. Assessment; and 8. Satisfaction.

Data analysis. The data were processed with different statistical programs depending on the type of information and analysis sought. The quantitative data obtained from the APMU scale was processed with SPSS software version 24.0. Instead, qualitative interview data were analyzed with QSR NVivo software, version 11.

Firstly, the values relating to the frequency and percentage of cases of GTP of m-learning were established according to gender, age, and university of affiliation. The possible existence of significant differences between these factors was also analyzed with the $T$-test for independent samples and ANOVA test.

For their part, the answers obtained from the structured interview were categorized and a content analysis was carried out as a method of data analysis (Bardín, 1991; López, 2002). The phases of the content analysis were: (a) detection of the frequency of appearance of terms as a previous step to establish the categories; (b) selection of the categories to be used; (c) live coding to specify the textual nodes (Piñuel, 2002; Strauss and Corbin, 2002). It should be noted that the Jaccard coefficient, used to group similar sets, was used in the live coding. The relationship between nodes was sought taking into consideration a correspondence index close to value 1 to ensure similarity between the nodes and guarantee the reliability of the results (Molina-Pérez and Luengo, 2020). Finally, the codification of the categories was represented graphically through the concept map technique, due to its relevance for knowledge representation (Yeung et al., 2018; Hwang et al., 2020). CmapTools software was used for this purpose.

\section{Results}

The sample was divided into two groups based on the scores obtained on the APMU scale: the application of m-learning was not classified as GTP (Non-GTP) $(60.44 \% ; n=680)$ and the application of m-learning was classified as GTP $(39.56 \% ; n=445)$ (Table 2). With regard to the socio-demographic variables, the percentages of cases of good practices were calculated as a proportion of the sample. Thus, the sample of men had a higher rate of application of good practices (41.94\%) than the population of women $(38.06 \%)$. Nevertheless, the difference in means was not 


\begin{tabular}{|c|c|c|c|c|c|c|}
\hline \multirow[t]{2}{*}{ Variables } & \multirow[t]{2}{*}{$n(\%)$} & \multicolumn{2}{|c|}{ Non-GTP } & \multicolumn{2}{|l|}{ GTP } & \multirow[t]{2}{*}{$\boldsymbol{p}$} \\
\hline & & $n$ & $\%$ & $n$ & $\%$ & \\
\hline \multicolumn{7}{|l|}{ Gender } \\
\hline Male & $434(38.6)$ & 252 & 58.06 & 182 & 41.94 & 0.196 \\
\hline Female & $691(61.4)$ & 428 & 61.94 & 263 & 38.06 & \\
\hline \multicolumn{7}{|l|}{ Age } \\
\hline $20-29$ & $79(7)$ & 44 & 55.7 & 35 & 44.3 & 0.851 \\
\hline $30-39$ & $293(26)$ & 182 & 62.12 & 111 & 37.88 & \\
\hline $40-49$ & $374(33.2)$ & 228 & 60.96 & 146 & 39.04 & \\
\hline $50-59$ & $281(25)$ & 163 & 58 & 118 & 42 & \\
\hline 60 or more & $98(8.7)$ & 63 & 64.28 & 35 & 35.72 & \\
\hline \multicolumn{7}{|l|}{ University } \\
\hline UAL & $12(1.1)$ & 4 & 33.3 & 8 & 66.7 & 0.000 \\
\hline UCA & $20(1.8)$ & 10 & 50 & 10 & 50 & \\
\hline UCO & $16(1.4)$ & 11 & 68.75 & 5 & 31.25 & \\
\hline UGR & $76(6.8)$ & 33 & 43.42 & 43 & 56.58 & \\
\hline UHU & $16(1.4)$ & 10 & 62.5 & 6 & 37.5 & \\
\hline UJAEN & $8(0.7)$ & 6 & 75 & 2 & 25 & \\
\hline UMA & $22(2)$ & 14 & 63.64 & 8 & 36.36 & \\
\hline UPO & $5(0.49)$ & 4 & 80 & 1 & 20 & \\
\hline US & $41(3.6)$ & 16 & 39.02 & 25 & 60.98 & \\
\hline ULOYOLA & $4(0.4)$ & 1 & 25 & 3 & 75 & \\
\hline UNIZAR & $39(3.5)$ & 19 & 48.72 & 20 & 51.28 & \\
\hline USJ & $6(0.5)$ & 5 & 83.33 & 1 & 16.67 & \\
\hline UNIOVI & $20(1.8)$ & 15 & 75 & 5 & 25 & \\
\hline ULL & $17(1.5)$ & 5 & 29.41 & 12 & 70.59 & \\
\hline ULPGC & $19(1.7)$ & 9 & 47.37 & 10 & 52.63 & \\
\hline UNICAN & $11(1)$ & 8 & 72.73 & 3 & 27.27 & \\
\hline UBU & $16(1.4)$ & 8 & 50 & 8 & 50 & \\
\hline UNILEON & $9(0.8)$ & 4 & 44.44 & 5 & 55.56 & \\
\hline USAL & $12(1.1)$ & 11 & 91.67 & 1 & 8.33 & \\
\hline UVA & $34(3)$ & 19 & 55.88 & 15 & 44.12 & \\
\hline UCAVILA & $2(0.2)$ & 2 & 100 & 0 & 0 & \\
\hline UPSA & $12(1.1)$ & 3 & 25 & 9 & 75 & \\
\hline UCLM & $23(2)$ & 15 & 62.22 & 8 & 34.78 & \\
\hline UAB & $25(2.2)$ & 18 & 72 & 7 & 28 & \\
\hline UB & $59(5.2)$ & 43 & 72.88 & 16 & 27.12 & \\
\hline UDG & $15(1.3)$ & 11 & 73.33 & 4 & 26.67 & \\
\hline UDL & $8(0.7)$ & 4 & 50 & 4 & 50 & \\
\hline URV & $15(1.3)$ & 9 & 60 & 6 & 40 & \\
\hline UAO & $3(0.3)$ & 3 & 100 & 0 & 0 & \\
\hline UIC & $10(0.9)$ & 7 & 70 & 3 & 30 & \\
\hline URL & $13(1.2)$ & 10 & 76.92 & 3 & 23.08 & \\
\hline UVIC & $8(0.7)$ & 5 & 62.5 & 3 & 37.5 & \\
\hline UAH & $16(1.4)$ & 11 & 68.75 & 5 & 31.25 & \\
\hline UAM & $29(2.6)$ & 17 & 58.62 & 12 & 41.38 & \\
\hline UCM & $53(4.7)$ & 37 & 69.81 & 16 & 30.19 & \\
\hline URJC & $8(0.7)$ & 4 & 50 & 4 & 50 & \\
\hline UAX & $1(0.1)$ & 1 & 100 & 0 & 0 & \\
\hline UCJC & $11(1)$ & 4 & 36.36 & 7 & 63.64 & \\
\hline UFV & $10(0.9)$ & 7 & 70 & 3 & 30 & \\
\hline UNEBRIJA & $6(0.5)$ & 3 & 50 & 3 & 50 & \\
\hline UCOMILLAS & $10(0.9)$ & 8 & 80 & 2 & 20 & \\
\hline UA & $27(2.4)$ & 11 & 40.74 & 16 & 59.26 & \\
\hline UJI & $18(1.6)$ & 11 & 61.11 & 7 & 38.89 & \\
\hline UV & $39(3.5)$ & 26 & 66.67 & 13 & 33.33 & \\
\hline CEU-UCH & $14(1.2)$ & 7 & 50 & 7 & 50 & \\
\hline UCV & $33(2.9)$ & 17 & 51.52 & 16 & 48.48 & \\
\hline UNEX & $31(2.8)$ & 22 & 70.97 & 9 & 29.03 & \\
\hline UDC & $10(0.9)$ & 6 & 60 & 4 & 40 & \\
\hline USC & $26(2.3)$ & 19 & 73.08 & 7 & 26.92 & \\
\hline UVIGO & $15(1.3)$ & 10 & 66.67 & 5 & 33.33 & \\
\hline UIB & $21(1.9)$ & 13 & 61.90 & 8 & 38.1 & \\
\hline UNIRIOJA & $6(0.5)$ & 2 & 33.33 & 4 & 66.67 & \\
\hline UNAVARRA & $14(1.2)$ & 9 & 64.29 & 5 & 35.71 & \\
\hline UNAV & $12(1.1)$ & 6 & 50 & 6 & 50 & \\
\hline UPV & $52(4.6)$ & 43 & 82.7 & 9 & 17.3 & \\
\hline DEUSTO & $20(1.8)$ & 16 & 80 & 4 & 20 & \\
\hline MONDRAGON & $5(0.4)$ & 2 & 40 & 3 & 60 & \\
\hline UM & $29(2.6)$ & 18 & 62.07 & 11 & 37.93 & \\
\hline UCAM & $13(1.2)$ & 8 & 61.54 & 5 & 38.46 & \\
\hline
\end{tabular}

significant $(p=0.196)$. The same happened with ages, no significant differences were obtained between them $(p=0.851)$. The age group of 20-29 years was the one where most experiences were concentrated (44.3\%).

Regarding the University to which they belong, the majority of cases where a percentage $>60 \%$ was obtained were at the University of La Laguna-ULL (70.59\%), University of Almería-
UAL (66.7\%), University of La Rioja-UNIRIOJA (66.67\%), Camilo José Cela University-UCJC (63.64\%), and University of Sevilla-US (60.98\%). Unlike the previous cases, between Universities if significant differences were confirmed $(p=0.000)$.

On the other hand, the information collected in the interviews was compiled into three concept maps, one for each GTP agent. Previously, the information was categorized by grouping similar sets and looking for the relationship between nodes with a correspondence index close to 1 . In this case, an index of 0.93 was obtained.

In relation to the sample, the first one belongs to the University of Granada (UGR) and was characterized by being a man with an age of 43 years old. He has a degree in Physical Education and has been teaching since 2007 . He came to dedicate himself to university teaching thanks to the insistence of one of his thesis directors. He also worked in other previous jobs, having worked as a physical education teacher in the stage of Obligatory Secondary Education. He emphasizes that what he likes most about his profession is being able to help students grow professionally and personally. The m-learning experience carried out in the classroom consisted of using a mobile application (app) to carry out the teaching-learning process, set in the film "In Time" (Fig. 1).

The second teaches at the Autonomous University of Madrid (UAM) and was characterized by being a man of 50 years of age. $\mathrm{He}$ has a degree in Mathematics and has been teaching since 1998. He even went on to teach at the university because he liked teaching. Furthermore, he has worked in an academy and in a primary school. He emphasizes that what he likes most about his profession is the atmosphere of working with young people, the interaction and the fact that he has to be constantly updating himself. The m-learning experience carried out in the classroom consisted of using the TikTok app as a means of sharing information (Fig. 2).

Finally, the third one works as a teacher at the University of Cantabria (UNICAN) and is a woman of 32 years old. She has a degree in Psychopedagogy and has been working as a teacher since 2013. She came to dedicate himself to university teaching after obtaining an FPU (University Teacher Training) scholarship from the Spanish Government. She also had other previous jobs, having worked in a library and in extracurricular activities in different educational centres. She emphasizes that what he likes best in her profession is teaching and research. The m-learning experience carried out in the classroom consisted of using three applications (Mentimeter, EDpuzzle, and Kahoot!) to carry out the teaching-learning process throughout the semester (Fig. 3).

The common aspects that were highlighted in all three experiences were (i) prior explanation of content; (ii) effective problem solving; (iii) group performance of tasks by students; (iv) the experience was applied over several years, is continuous over time; (v) evaluation was based on self-assessment or student participation (self-regulation); and (vi) there is a high satisfaction in the experiences, where increased student motivation and achievement of meaningful learning was highlighted.

\section{Discussion}

The data showed that almost $40 \%$ of the population carried out a GTP of m-learning, which indicates that m-learning in Spain is having an evolution according to what was specified in the Horizon Report (Alexander et al., 2019). The percentage obtained was high considering that there were no previous studies that identified the development of GTP of m-learning at a national level. In this sense, Spanish university professors have considerable experience in the use of mobile devices in the classroom. However, no specific teacher profile is highlighted, as there were no significant differences according to gender and age. 
Good Teaching Practice M-learning

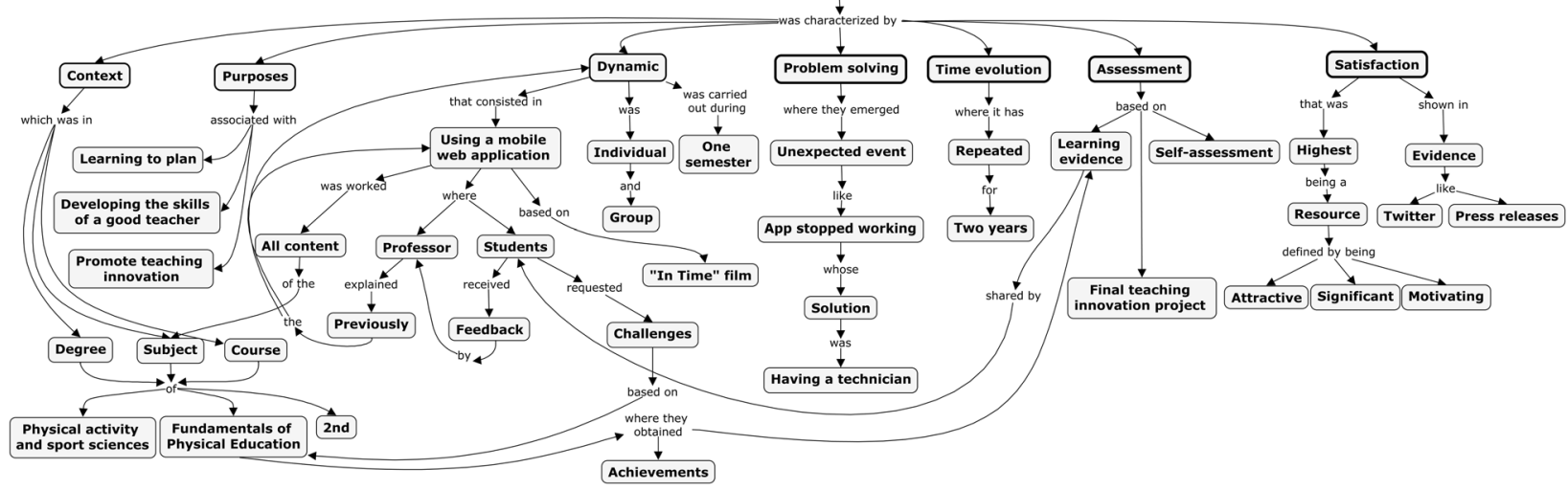

Fig. 1 Experience of good teaching practices of m-learning in UGR.

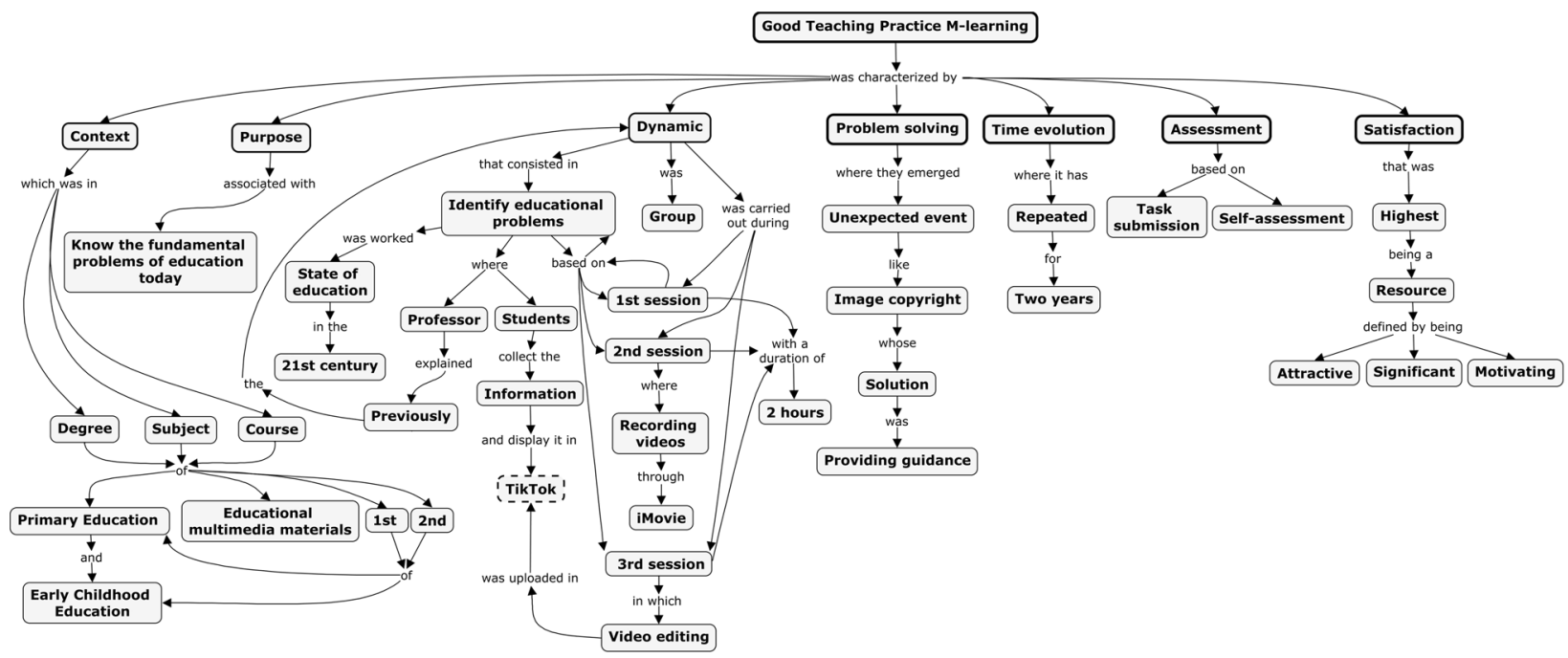

Fig. 2 Experience 2 of good teaching practices of m-learning in UAM.

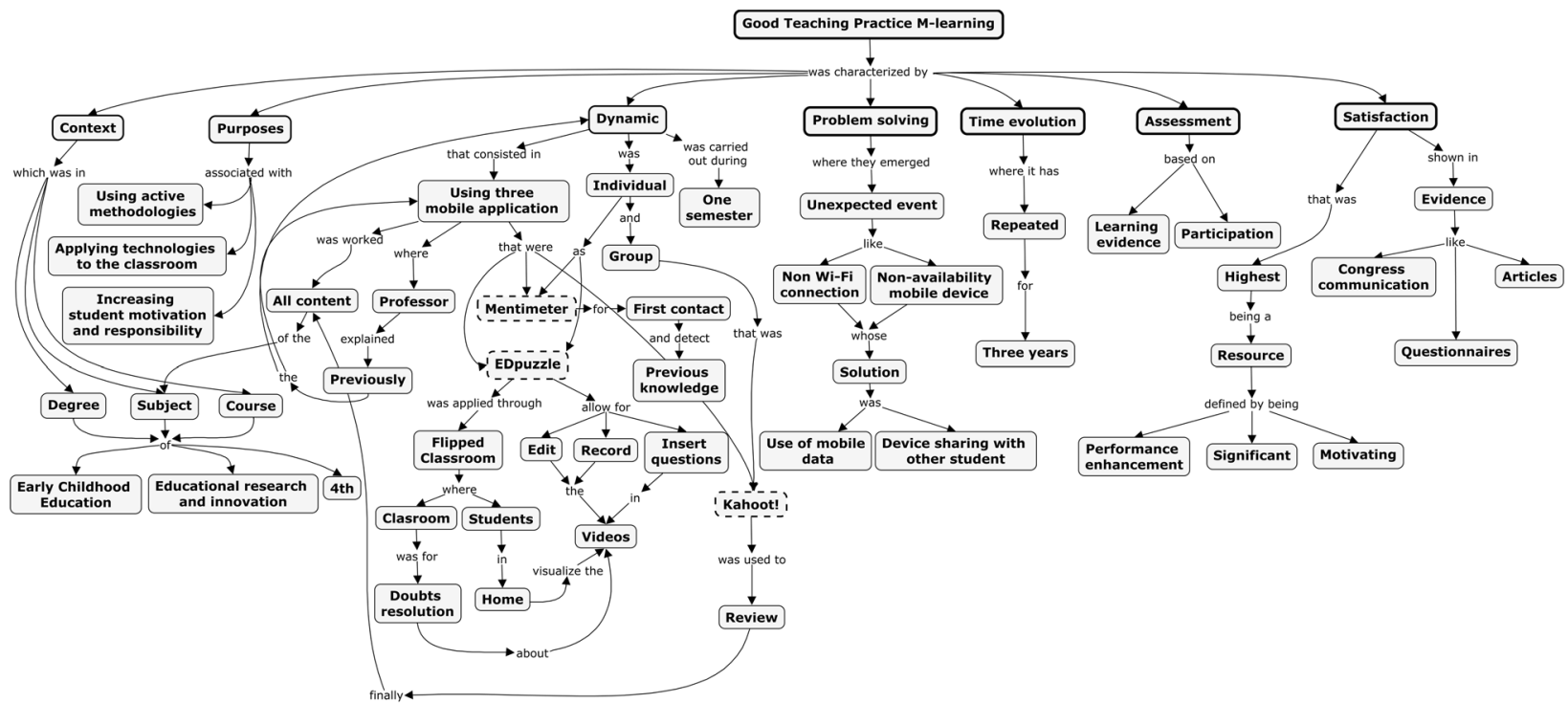

Fig. 3 Experience 3 of good teaching practices of m-learning in UNICAN. 
The differences were found among universities, where the ULL was the one with the highest number of cases detected, more than $70 \%$. Therefore, it can be inferred that this University has an important commitment to the use of technology in the centre. On the other hand, overall, the highest rate of GTP is found in the universities of Andalusia, collecting almost 25\% of all GTP in Spain. Educational plans and plans for the inclusion of technology in Andalusian universities have had an impact on this aspect, with a commitment to the use of Information and Communication Technologies (ICT) as a transformative teaching practice being fundamental (Boude, 2019).

Specifically, the three agents of GTP who were interviewed are vocational teachers who are committed to educational innovation. These are driving teachers based on their experience in applying m-learning (Salcines-Talledo et al., 2017), who have been using this resource for several years.

In addition, it highlights its commitment to the use of active learning methodologies. Bearing in mind that the focus is on the student. So m-learning has been one of its main teaching methods. However, one of them combines this method with the flipped classroom, being totally compatible and recommended the use of different methodologies based on ICT. Futhermore, some of its activities have required the use of a mobile application to maintain communication and the completion of tasks (UGR experience), the creation and editing of videos (UAM experience) and constant interaction with three applications for the development of tasks (UNICAN experience). Therefore, the m-learning experiences developed have involved different areas of digital competence (INTEF, 2017) and therefore, their development (Fuentes et al., 2019; Rodríguez et al., 2017; Pinto et al., 2019). Along the same lines as indicated by the definition of GTP for $\mathrm{m}$ learning (Aznar-Díaz et al., 2018).

On the other hand, different factors that can be categorized as fundamental were common to all $\mathrm{m}$-learning practices. The first of these was the prior explanation of the content. So, establishing guidelines to explain both the dynamics to be carried out and the applications to be used is an aspect to be taken into account in the development of good practices of m-learning. The second was effective problem solving. Teachers must therefore anticipate any adverse situation and have an alternative plan in place in case something unexpected happens. The third was the group performance of tasks by students, related to a common aspect of GTP with ICT: the promotion of collaborative work (Alonso-García et al., 2019). The fourth factor was the fact that the experience was applied over several years. So these were continuous practices over time, which have been perfected and good results are obtained every year. The fifth was that assessment was based on student selfassessment or participation, thus promoting self-regulation through mobile devices (Hossain et al., 2019; Lim et al., 2019). And finally, the sixth factor was related to the high satisfaction with the mlearning experiences, which involved increasing student motivation and achieving significant learning (Bai, 2019; Fox, 2019; Gil, 2019).

In short, fundamental aspects have been collected to advance knowledge about GTP of m-learning in Spain. Following the line of the few previous studies that there are currently on this topic (Caldeiro-Pedreira et al., 2018; González-Fernández and SalcicesTalledo, 2017; Navarro et al., 2018).

\section{Conclusions}

GTP of $\mathrm{m}$-learning have taken place in different settings and with different teaching profiles. Therefore, there is no specific profile of a teacher who carries out successful practices, but any teacher can do it if he or she takes into account certain factors.

Specifically, this work is a pioneering study that collects data from all Spanish universities. It is pioneering insofar as a quantitative scale has been used to detect GTP and, based on this, to select teachers who are agents of good practices who have been interviewed in order to obtain three reference models that can be transferred to other contexts.

These three models have particular experiences, but with satisfactory results in student learning. Adapting these experiences to other scenarios is possible. So teachers who want to start m-learning have successful models at their disposal as a reference.

In turn, the work has addressed the objectives set out in a satisfactory manner where m-learning practices implemented by Spanish university teachers have been evaluated and experiences on GTP of m-learning developed in the classroom have been compiled.

Finally, the limitations of the study are the limited sample size in some universities, and there is an imbalance between them. However, it was decided to maintain these cases to ensure the representativeness of all the universities with face-to-face teaching in Spain. As future lines of research, it is recommended to continue investigating GTP of m-learning and to reverse the trend in research, which is mostly based on research on perceptions and adoption of m-learning in a theoretical way. So that a more practical line of research related to the real application in the classroom is initiated, as in this study where models of experiences based on GTP of m-learning are collected.

In the end, educating in the good use of technology through GTP is key to favouring a better society in harmony with technology, avoiding its abuse and the development of addictive behaviors.

\section{Data availability}

Due to privacy reasons, the datasets analyzed during the current study are not publicly available but are available from the corresponding author on reasonable request.

Received: 21 March 2020; Accepted: 15 April 2020;

Published online: 05 May 2020

\section{References}

Alexander B, Ashford-Rowe K, Barajas-Murphy N, Dobbin G, Knott J, McCormack M, Weber N (2019) EDUCAUSE horizon report: 2019 higher education edition. EDUCAUSE, Louisville

Alonso-García S, Aznar-Díaz I, Cáceres-Reche MP, Trujillo-Torres JM, RomeroRodríguez JM (2019) Systematic review of good teaching practices with ICT in Spanish higher education. Trends and challenges for sustainability. Sustainability 11(24):7150. https://doi.org/10.3390/su11247150

Arain AA, Hussain Z, Rizvi WH, Saleem M (2019) Extending UTAUT2 toward acceptance of mobile learning in the context of higher education. Univers Access Inf Soc 18:659-673. https://doi.org/10.1007/s10209-019-00685-8

Arpaci I, Unver TK (2020) Moderating role of gender in the relationship between big five personality traits and smartphone addiction. Psychiatr Q. https://doi. org/10.1007/s11126-020-09718-5

Aznar-Díaz I, Cáceres-Reche MP, Romero-Rodríguez JM (2018) Quality indicators to evaluate good teaching practices of mobile learning in higher education. Educ Knowl Soc 19(3):53-68. https://doi.org/10.14201/eks20181935368

Aznar-Díaz I, Cáceres-Reche MP, Romero-Rodríguez JM (2019) Digital competence of an e-learning tutor: an emerging model of good teaching practices in ICT. Texto Livre 12(3):49-68. https://doi.org/10.17851/1983-3652.12.3.49-68

Bai H (2019) Pedagogical practices of mobile learning in K-12 and higher education settings. TechTrends 63:611-620. https://doi.org/10.1007/s11528-019-00419-w

Bardín L (1991) Análisis de contenido. Akal, Madrid

Benali M, Ally M (2020) Towards a conceptual framework highlighting mobile learning challenges. Int J Mob B Learn 12(1):4. https://doi.org/10.4018/IJMBL.2020010104

Boude OR (2019) How teachers integrate mobile devices in the classroom. Espacios 40(29):2

Caldeiro-Pedreira MC, Yot-Domínguez C, Castro-Zubizarreta A (2018) Detection of mobile devices-based good educational practices in primary school. Prism Soc 20:58-75

Cevik C, Cigerci Y, Kilic I, Uyar S (2020) Relationship between smartphone addiction and meaning and purpose of life in students of health sciences. Perspect Psychiatr Care. https://doi.org/10.1111/ppc.12485 
Chen CY (2020) Smartphone addiction: psychological and social factors predict the use and abuse of a social mobile application. Inf Commun Soc 23(3):454-467. https://doi.org/10.1080/1369118X.2018.1518469

Díez LF, Valencia A, Bermúdez J (2017) Agent-based model for the analysis of technological acceptance of mobile learning. IEEE Lat Am Trans 15 (6):1121-1127. https://doi.org/10.1109/tla.2017.7932700

Fagan MH (2019) Factors influencing student acceptance of mobile learning in higher education. Comput Sch 36(2):105-121. https://doi.org/10.1080/ 07380569.2019 .1603051

Fernández A, Maiques JM, Abalós A (2012) The good teaching practice of university professors: case study. REDU 10(1):43-66

Fox E (2019) Mobile technology: a tool to increase global competency among higher education students. IRRODL 20(2):242-259

Fuentes JL, Albertos JE, Torrano F (2019) Towards the mobile-learning in the school: analysis of critical factors on the use of tablets in Spanish schools. Educ Knowl Soc 20:3. https://doi.org/10.14201/eks2019_20_a3

Gil J (2019) Interconnected bets for the collective construction of knowledge. Mobile learning in infant and primary education. Pixel-BIT 54:185-203. https://doi.org/10.12795/pixelbit.2019.i54.10

Gómez-Ramírez I, Valencia-Arias A, Duque L (2019) Approach to M-learning acceptance among university students: an integrated model of TPB and TAM. IRRODL 20(3):141-164. https://doi.org/10.19173/irrodl.v20i4.4061

González F, Guruceaga A, Pozueta E, Porta S (2010) An approximation to the knowledge of a university lecturer who is a recognised good teaching practitioner, using concept maps. Profesorado 14(3):117-130

González-Fernández N, Salcices-Talledo I (2017) Mobile learning in the grade of children education. A good practice in the University of Cantabria. IEYA 3 (2):71-76. https://doi.org/10.22370/ieya.2017.3.2.702

Hoi VN (2020) Understanding higher education learners' acceptance and use of mobile devices for language learning: a Rasch-based path modeling approach. Comput Educ 146:103761. https://doi.org/10.1016/j.compedu.2019.103761

Hossain S, Abdou BO, Kettunen J, Gregory S (2019) A phenomenographic research study of students' conceptions of mobile learning: an example from higher education. SAGE Open 1-17. https://doi.org/10.1177/2158244019861457

Hwang GJ, Zou D, Lin J (2020) Effects of a multi-level concept mapping-based questionposing approach on students' ubiquitous learning performance and perceptions. Comput Educ 149:103815. https://doi.org/10.1016/j.compedu.2020.103815

Irugalbandara TC, Fernando MSD (2019) Context aware adaptive mobile learning framework for bottom of pyramid people (BOP). Int J Adv Appl Sci 6 (12):27-40. https://doi.org/10.21833/ijaas.2019.12.004

Israel DJ, Velu R (2019) The partial test of UTAUT model to explain the influence of variables on the intention to adopt the mobile learning in higher education. IJITEE 8(8):1076-1082

Jahnke I, Liebscher J (2020) Three types of integrated course designs for using mobile technologies to support creativity in higher education. Comput Educ 146:103782. https://doi.org/10.1016/j.compedu.2019.103782

Jinot BL (2019) An evaluation of a key innovation: mobile learning. Acad J Interdiscip Stud 8(2):39-45. https://doi.org/10.2478/ajis-2019-0014

Johnson RB, Onwuegbuzie AJ (2004) Mixed methods research: a research paradigm whose time has come. Educ Res 33(7):14-26. https://doi.org/10.3102/ 0013189x033007014

Kaliisa R, Palmer E, Miller J (2019) Mobile learning in higher education: a comparative analysis of developed and developing country contexts. Br J Educ Technol 50(2):546-561. https://doi.org/10.1111/bjet.12583

Kumar JA, Bervell B (2019) Google classroom for mobile learning in higher education: modelling the initial perceptions of students. Educ Inf Technol 24:1793-1817. https://doi.org/10.1007/s10639-018-09858-z

Kumar JA, Sumi S, Verma A, Verma S (2019) Use of smartphones for academic purposes by teachers of Panjab University. IJRTE 7(6S5):290-294

Lim G, Shelley A, Heo D (2019) The regulation of learning and co-creation of new knowledge in mobile learning. Knowl Manag E-Learn 11(4):449-484. https:// doi.org/10.34105/j.kmel.2019.11.024

López F (2002) Content analysis as a research method. XXI. Rev Educ 4:167-179

López FA, Silva MM (2016) Factors of mobile learning acceptance in higher education. Estud sobre educ 30:175-195. https://doi.org/10.15581/004.30.175-195

Martínez B (2011) Good teaching practices in secondary education. EDETANIA 39:101-112

Molina-Pérez J, Luengo J (2020) "Resilient" reconstructions of teachers professional identity: endoprivatization and performative culture in Andalusia (Spain). REICE 18(2):57-75. https://doi.org/10.15366/reice2020.18.2.003

National Institute of Educational Technologies and Teacher Training of Spain (INTEF) (2017) Marco Común de Competencia Digital Docente. Ministry of Education, Culture and Sport, Spain

Navarro RJ, Vega MV, Chiroque E, Rivero C (2018) Teacher's perception on good practices with a mobile application for teaching mathematics. Educación 27 (52):81-97
Pereira Z (2011) Mixed Method designs in education research: a particular experience. Rev Electrón Educ 15(1):15-29

Pinto M, Gómez-Hernández JA, Sales D et al. (2019) Learning and teaching digital skills in a mobile environment: advances of a research on university professors and students of Social Sciences degree. R.Ibero-am Ci Inf 12 (2):585-596. https://doi.org/10.26512/10.26512/rici.v12.n2.2019.23590

Piñuel JL (2002) Epistemology, methodology and content analysis techniques. Estud Socioling 3(1):1-42

Qi C (2019) A double-edged sword? Exploring the impact of students' academic usage of mobile devices on technostress and academic performance. Behav Inf Technol 38(12):1337-1354. https://doi.org/10.1080/0144929X.2019.1585476

Rodríguez H, Restrepo LF, García G (2017) Digital skills and use of smartphone for learning in higher education. Rev Virtual Univ Catól Norte 50:126-142

Salcines-Talledo I, González-Fernández N, Briones E (2017) Lecturers profiles: knowledge and professional use of smartphones. Bordón 69(2):97-114

Saroia AI, Gao S (2019) Investigating university students' intention to use mobile learning management systems in Sweden. Innov Educ Teach Int 56 (5):569-580. https://doi.org/10.1080/14703297.2018.1557068

Stilgoe J (2016) Scientific advice on the move: the UK mobile phone risk issue as a public experiment. Palgrave Commun 2:16028. https://doi.org/10.1057/ palcomms.2016.28

Strauss A, Corbin J (2002) Bases de la investigación cualitativa. Técnicas y procedimientos para desarrollar la teoría fundamentada. University of Antioquía, Colombia

Vacas AA, Niño JI, Álvarez S (2019) Use of a mobile app to improve the quality of university teaching: a neuromarketing study. Prism Soc 27:65-85

Valles MS (2009) Entrevistas cualitativas. Centro de Investigaciones Sociológicas, Madrid

Vasilevski N, Birt J (2020) Analysing construction student experiences of mobile mixed reality enhanced learning in virtual and augmented reality environments. Res Learn Technol 28:2329. https://doi.org/10.25304/rlt.v28.2329

Xue SJ (2020) A conceptual model for integrating affordances of mobile technologies into task-based language teaching. Interact Learn Environ. https://doi. org/10.1080/10494820.2019.1711132

Yeung CL, Wang WM, Cheung CF, Tsui E, Setchi R, Lee RWB (2018) Computational narrative mapping for the acquisition and representation of lessons learned knowledge. Eng Appl Artif Intell 71:190-209. https://doi.org/10.1016/j. engappai.2018.02.011

Zabalza MA (2012) The study of "best teaching practices" in Higher Education. REDU 10(1):17-42

\section{Acknowledgements}

This paper has been funded by the Ministry of Education, Culture and Sport of the Government of Spain (Reference FPU16/01762).

\section{Competing interests}

The authors declare no competing interests.

\section{Additional information}

Correspondence and requests for materials should be addressed to J.-M.R.-R.

Reprints and permission information is available at http://www.nature.com/reprints

Publisher's note Springer Nature remains neutral with regard to jurisdictional claims in published maps and institutional affiliations.

Open Access This article is licensed under a Creative Commons Attribution 4.0 International License, which permits use, sharing, adaptation, distribution and reproduction in any medium or format, as long as you give appropriate credit to the original author(s) and the source, provide a link to the Creative Commons license, and indicate if changes were made. The images or other third party material in this article are included in the article's Creative Commons license, unless indicated otherwise in a credit line to the material. If material is not included in the article's Creative Commons license and your intended use is not permitted by statutory regulation or exceeds the permitted use, you will need to obtain permission directly from the copyright holder. To view a copy of this license, visit http://creativecommons.org/ licenses/by/4.0/

(C) The Author(s) 2020 